\title{
Review on Emerging and Reemerging Microbial Causes in Bovine Abortion
}

\author{
S. Parthiban*, S. Malmarugan, M. S. Murugan, J. Johnson Rajeswar, P. Pothiappan \\ Department of Veterinary Microbiology, Veterinary College and Research Institute, Tamilnadu Veterinary and Animal Sciences University, \\ Tirunelveli-627 358, Tamilnadu, India
}

\section{Email address:}

parthis17@gmail.com (S. Parthiban)

\section{To cite this article:}

S. Parthiban, S. Malmarugan, M. S. Murugan, J. Johnson Rajeswar, P. Pothiappan. Review on Emerging and Reemerging Microbial Causes in Bovine Abortion. International Journal of Nutrition and Food Sciences. Special Issue: Review on Novel Approaches for the Management of Emerging and Reemerging Livestock Diseases. Vol. 4, No. 4-1, 2015, pp. 1-6. doi: 10.11648/j.ijnfs.s.2015040401.11

\begin{abstract}
This review summarizesemergingand re-emergingmajor bacterial, fungal, viral and protozoan causes of abortion in cattle. The clinical presentations of disease due to reproductive pathogens are emphasized, with afocus on assisting development of complete lists of major causes that result in abortion in cattle. Clinicians areencouraged to assess clinical presentation, create complete lists of differential diagnoses, obtain appropriate diagnostic samples, maximize diagnostic laboratory support, and avoid zoonotic infections resulting from reproductive pathogens of animals. Thefoundation of an accurate diagnosis of reproductive loss due to infectious pathogens facilitates the prudent use of immunization andbiosecurity to minimize reproductive losses.
\end{abstract}

Keywords: Emerging Pathogens, Re-Emerging Pathogens, Bovine, Abortion

\section{Introduction}

An emerging disease is defined as a new infection resulting from the evolution or change of an existing pathogen or parasite resulting in a change of host range, vector, pathogenicity or strain; or the occurrence of a previously unrecognised infection or disease. A re-emerging disease is considered an already known disease that either shifts its geographical setting or expands its host range, or significantly increases its prevalence. Abortions have a highly negative impact on reproductive efficiency, resulting in significant economic losses for the cattle industry [1] Under optimal laboratorial conditions, etiologic diagnosis is achieved in 23.3 to $45.5 \%$ of the cases [2]. Abortion is a devasting condition associated with major economic loss in the bovine industry caused by various emerging and re emerging pathogens. Bovine abortion may be due to infectious, toxic, endocrine, physical or nutritional causes. Infectious agents associated with abortion in cattle include viruses, bacteria, protozoa, and fungus. The exact proportion of cases due to infectious agents is not known, but in $90 \%$ of cases in which an etiologic diagnosis is achieved the cause is infectious.Foetal death is the most important condition that limits cow's ability to producea calf and considerably erodes the profit. If death occurs at 1 or 2 months of gestation, it is usually termed "early embryonic death." This loss of an embryo early in gestation is generally associated with no evident clinical signs in the cow that the pregnancy has terminated. After 2 months of gestation there is usually clinical evidence of a "foetal loss" which is expulsion of the foetus and foetal tissues. When the foetus in near term and born dead it is often called "stillbirth". This stillbirth could have occurred due to difficult birth and the death of thefoetus, or it may have died in-utero due to disease and was expelled. Depending upon the cause of "abortion" a cow may experience, foetal loss, embryonic loss or a still birth.

The infectious causes include bacterial, mycotic, viral, and protozoa. Symptoms are usually similar and diagnosis requires the services of a trained veterinarian and often the veterinary laboratory. The symptoms of infections in most animals are similar regardless of the cause of infection[3]. Aborted foetuses are usually not found, but cows may have creamy white discharge from the vulva.Some farmers may not even realize that there is a problem until an unusually large number of cows arediagnosed "empty" at the time of pregnancy checking. Some of theimportant infectious causes of bovine abortion are discussed below. 


\section{Bacterial Organisms Involved in Bovine Abortion}

Bacterial abortions result from brucellosis, leptospirosis, campylobacteriosis (vibriosis), listeriosis, Haemophilus somnuscomplex, and ureaplasmosis. Bacterialike Salmonella, Actinomyces, Escherichia coli, Streptococcus,
Staphylococcus, Bacillus, Pseudomonas, Proteus, Pasteurella Nocardia, and chlamydia species, as determined by the microbiologicalfindings, can cause abortion[4]. All these organisms and few others that are not listed have been isolated from sporadic cases of abortion. These are secondary to either a septicemia in the dam or ascending infection through thevagina and cervix or due to persistentendometritis.

Table 1. Common bacterial causes of bovine abortion.

\begin{tabular}{|c|c|c|c|c|}
\hline S.No & Infectious agent & Time of abortion & Lesions & Samples for diagnosis \\
\hline 1. & $\begin{array}{l}\text { Brucella abortus } \\
\text { Brucellosis-Bang's disease }\end{array}$ & $\begin{array}{l}6-9 \text { months. Abortion } \\
\text { or stillbirth } 2 \text { wk to } 5 \\
\text { mo after infection }\end{array}$ & $\begin{array}{l}\text { Placenta: retained, cotyledons necrotic, red-yellow, } \\
\text { area between thickened. Calf: normal or autolytic } \\
\text { with bronchopneumonia }\end{array}$ & $\begin{array}{l}\text { placenta, foetus, or } \\
\text { uterine discharge }\end{array}$ \\
\hline 2. & $\begin{array}{l}\text { Campylobacter foetus } \\
\text { venerealis Vibriosis }\end{array}$ & $5-8$ months & $\begin{array}{l}\text { Placenta: mild placentitis, hemorrhagic cotyledons } \\
\text { and an edematous intercotyledonary area.Foetus: } \\
\text { fresh or autolysed; mild fibrinous pleuritis, } \\
\text { peritonitis, bronchopneumonia. }\end{array}$ & $\begin{array}{l}\text { Placenta, foetal abomasal } \\
\text { contents, vaginal flushing }\end{array}$ \\
\hline 4. & $\begin{array}{l}\text { Arcanobacterium } \\
\text { (Actinomyces) pyogenes }\end{array}$ & Any stage & $\begin{array}{l}\text { Placenta: endometritis and diffuse placentitis, reddish } \\
\text { brown to brown colour.Foetus: autolysed, fibrinous } \\
\text { pericarditis, pleuritis, or peritonitis }\end{array}$ & Placenta, foetus \\
\hline 5. & Listeria monocytogenes & Last trimester & $\begin{array}{l}\text { Dam: fever, inappetancePlacenta: retained. Foetus: } \\
\text { autolysed Fibrinous polyserositis and white necrotic } \\
\text { foci in the liver and/or cotyledons }\end{array}$ & Placenta, foetus \\
\hline
\end{tabular}

\subsection{Brucellosis}

Bovine brucellosis is the wellknown and most controversial infection of the bovine reproductive system. Brucellosis generally has been thought of as a cattle disease, but it is also seen in swine, sheep, goats, dogs, horses and wildlife, and can be readily transmitted to humans. The disease represents a real occupational hazard for veterinarians, slaughter men, and cattle producers. Brucellosis is caused by the bacterium Brucella abortus. The organism has an affinity for certain body tissues such as the udder, uterus, lymph nodes, testicles, and accessory glands. Because of its affinity for the uterus, abortion is the usual sign of the disease[3].

It $\mathrm{s}$ difficult to identify infected cattle by theirappearance, all infected cattle does not abort. In addition, the incubation periodfor brucellosis is variable. Brucellosis is primarily transmitted to susceptible animals by direct contact with infected animals. Essentially, the only time an infected cow transmits the organism is at or around calving or abortion. Aborted foetuses, placental membranes, placental fluids, and thevaginal discharges that persist for several days after an infected cow has calved or aborted contaminate surroundings all around with virulentBrucella organisms. The organism may be transmitted to other animals that contact the environment that hasbeen contaminated with discharges from infected animals[5]. Milk andcolostrum from infected cows are the readily available source of infection for calves and the human population. Because brucellosis can easily be transmitted to people, asepticprocedures such as using disposablegloves when examining or assisting cows at calving are highly recommended. Cattle can generally be moved interstate from brucellosis free states without testing. Just because an animal or group of animals has been tested and declared free of infection does not ensure that some are not in the incubation stage of the disease

Therefore, any newly purchased cattleshould be quarantined and retested in 45-120 days. This may be the most important part of a preventive program, and one over which the buyer has complete control. A relatively new RB51 vaccine has replaced the old Strain 19, the only vaccine available for many years. The biggest advantage of the RB51 vaccine is almost total elimination of false positives observed with use of Strain19. Use of Strain 19 often resulted in antibody titers that were difficult to differentiate from actual infection titers. Heifer calves can be vaccinated between the ages of 4 and 12 month; about 6 months of age is best[6].

\subsection{Leptospirosis}

Leptospirosis is a contagious, bacterial disease of animals and humans. In cattle, horses, pigs, sheep, goats, and dogs, it has been characterized by a wide variety of conditions including fever, icterus, hemoglobinuria, abortion, and death. However, the concept of this disease has recently changed. It is used to be considered a highly fatal disease, but is now thought to be a widespread, mostly subclinical infection of many species of wild and domestic animals. Signs of leptospirosis in cattle embryonic death and prolonged to acute infections that end in death

Cattle are the maintenance hosts for Leptospira interrogans serovar hardjo (type hardjoprajitno) and Leptospira borgpeter-senii serovar hardjo (type hardjo-bovis) 
and incidental hosts for serovar pomona which is maintained in swine[5].Transmission among maintenance hosts is through contact with infected urine, milk, placental fluid, transplacentally, or venereally. Transmission to anincidental host occurs via contact with an environment contaminated with infected urine. The bacteria gain access through the mucous membranes of the eyes, nose, vagina, or abraded skin. Infection in pregnant animals can lead to abortion, stillbirth, or birth of weak calves.

Abortion following infection with serovar Pomona occurs in the last trimester, whereas abortion caused by serovar hardjo occurs from 4 months of gestation to term. Abortion rates within a temporal "outbreak" are generally higher following infection with serovarpomona compared with hardjo. Infertility is also considered to occur with serovar hardjo infection.Antibodies first appear in the serum of infected animals by the sixth or seventh day, and titers rise rapidly to a high level. Titers then decline to a more or less constant level and may persist for months. Samples sent to the laboratory for culture must be collected and shipped as rapidly as possible because leptospiras do not survive long in dead tissue. Vaccination with killed bacteria protects against clinical leptospirosis for up to a year, but the bacteria must contain the antigens of the strain to which the animal are exposed[6].

\subsection{Campylobacteriosis}

Campylobacteriosis (vibriosis) isa venereal disease of cattle caused by the organism Campylobacter foetu sub species foetus. Before 1973, this organism was known as Vibrio foetus subspecies venerealis. Campylobacteriosis is characterized by infertility with an increased number of services necessary for conception. Early embryonic deaths are common. In a herd that has never been exposed, and where no immunity exists, an acute type of infertility problem develops[5].In this case, infertility caused by endometritis results in early in cattle embryonic death and a prolongedunapparent infections period (up to $120+$ days) passes before. Successful conception occurs. Spread of the organism to the male is primarilyby copulation with the infected female.

A definite diagnosis of genitalcampylobacteriosis can be difficult and laboratory test results are often disappointing. Although blood tests are available, they are not reliable because it is not a systemic disease and antibodies are rarely found in the bloodstream. Most infected heifers rid themselves of the organism within 6months of sexual rest, thus a reduction of demonstrable antibodies occurs. Bacteriological examination of aborted foetuses appears to be the only practical method of confirming the diagnosis later in gestation. Without vaccination, control and prevention of this disease can be difficult. Both killed and modified-live vaccines are available. Vaccination of bulls has been reported to be effective for both prevention and also as a cure for Campylobacter foetus infection. Initial vaccination should consist of two injections before breeding time[7].

\subsection{Listeriosis}

Listeria monocytogenes is a wellrecognized cause of abortion, encephalitis and septicaemia in cattle. L. ivanovii has also been implicated as a cause of abortion in cattle but occurs less frequently than $L$. monocytogenes.Listeric infections and abortions usuallydevelop in the late winter or early spring. Abortions are most commonly recognized in the last trimester of pregnancy[5].L. monocytogenes and $L$. ivanoviiwere isolated from buffaloes, cows, does and ewes with reproductivedisorders (endometritis, repeatbreeding). The organism is, so far,usually sensitive to a wide range ofantibiotics. Ampicillin, amoxicillin,tetracyclines, chloramphenicol, betalactum antibiotics, together with anaminoglycoside, trimethoprim andsulphamethoxazole arerecommended. Culling infectedanimals should be advocated as they secrete the organisms in secretionsand excretions, especially in the casesof mastitis. Care in the use andpreparation of silage is important asthe pathogen grows luxuriantly at a pHgreater than[8].

\section{Viral Causes of Bovine Abortion}

Table 2. Common viral causes of bovine abortion

\begin{tabular}{|c|c|c|c|c|}
\hline S.No & Infectious agent & Time of abortion & Lesions & Samples for diagnosis \\
\hline 1. & $\begin{array}{l}\text { Bovine Viral Diarrhoea Virus (BVD- } \\
\text { MD) }\end{array}$ & $\begin{array}{l}\text { Abortion usually up to } 4 \\
\text { months }\end{array}$ & $\begin{array}{l}\text { Placenta: retained, no specific lesions. } \\
\text { Foetus: no specific lesions, autolysed, } \\
\text { mummified }\end{array}$ & $\begin{array}{l}\text { Placenta, foetus (preferred - } \\
\text { spleen), dam and herd mates } \\
\text { serum }\end{array}$ \\
\hline 2. & $\begin{array}{l}\text { Bovine Herpesvirus type I (BHV I) } \\
\text { Infectious Bovine rhinotracheitis } \\
\text { virus }\end{array}$ & $\begin{array}{l}\text { Possibly any stage but } \\
\text { most commonly from } 4 \\
\text { months to term }\end{array}$ & $\begin{array}{l}\text { Placenta: necrotizing vasculitisFoetus: } \\
\text { autolysed, foci of necrosis in the liver }\end{array}$ & $\begin{array}{l}\text { Placenta, foetus, serum } \\
\text { samples from the dam }\end{array}$ \\
\hline 3. & $\begin{array}{l}\text { Blue tongue virus } \\
\text { Blue tongue }\end{array}$ & Variable & Foetus: autolysed & $\begin{array}{l}\text { Placenta, foetus, serum } \\
\text { samples from the dam }\end{array}$ \\
\hline
\end{tabular}

\subsection{IBRT (Infectious BovineRhinotracheitis) Virus}

Infectious Bovine Rhinotracheitis or "Red Nose" is caused by bovine herpesvirus 1 is an alpha herpesvirus that can lead to respiratory and genital infections, as well as abortion [9, 10]. Transmission occurs through contact with upper respiratory, conjunctival or genital tract mucous membranes, aborted fetuses, or through venereal transmission. Abortions are most commonly associated with the respiratory form of the disease and not the genital form. Cows can have fever, anorexia, red nasal mucosa, coughing, and conjunctivitis, followed by abortion in 15-64 d. Abortion generally occurs 
between 4 and 8 months of gestation. Infection also can result in early embryonic death [11]. Bovine herpesvirus 1 establishes latent infections in the trigeminal and sacral ganglia; following immunosuppression, the virus can become reactivated. Therefore, these animals serve as a source of infection forunexposed cattle. A diagnosis of IBR-induced abortion is made by laboratory examination and testing of foetal tissues. A bl09d test may aid in the identification of infected cattle. The control of IBR infections can be accomplished by the use of vaccines[8].

\subsection{Bovine Viral Diarrhoea (BVD)}

Bovine viral diarrhoea is a complex viraldisease of cattle and is a major cause ofeconomic loss. It can affect all ages ofcattle with the most important effect on herdfertility resulting from infection of theunborn calf. The impact of the BVD dependson the stage of pregnancy. Bovine viral diarrhea virus is a Pestivirus that is transmitted transplacentally or through inhalation oringestion of material contaminated with infected secretions[12]. Animals with acute infection presentwith fever, nasal discharge, enteritis, and leukopenia. Pregnant animals infected up to $45 \mathrm{~d}$ of gestation canhave decreased fertilization rates and embryonic death. Infection between 45 and $175 \mathrm{~d}$ of gestation can resultin abortion; however, fetuses that survive infection with a noncytopathic strain of BVDV between 70 and 150 dof gestation usually become persistently infected (PI). Animals that are PI shed large amounts of BVDV andgenerally do not produce antibodies to BVDV. These animals can be stunted in growth or appear normal. Fetal infection occurring at 100 $150 \mathrm{~d}$ of gestation can result in congenital abnormalities, including cerebellarhypoplasia, microencephalopathy, cataracts, microopthalmia, and thymic aplasia. Fetuses infected between 150 and $285 \mathrm{~d}$ of gestation are usually able to clear the virus, develop normally, and exhibit precolostral neutralizing antibodies to BVDV[11].

\subsection{Bluetongue Virus}

Bluetongue virus is an orbivirus that is transmitted by a midge Culicoides variipennis[13]. Fetuses infected during the first $100 \mathrm{~d}$ of gestation, resorb or abort. Infections between 75 and $100 \mathrm{~d}$ of gestation can result in stillbirths, birth of weak calves, or birth of calves with cerebral abnormalities. Infection after Day 150 of gestation does not generally have a negative effect on the fetus[11].

\section{Mycotic and ProtozoalCauses of Abortion in Bovines}

Protozoal diseases causingabortion are Trichomoniasis, Sarcocystosis ("Sarcosporidiosis") and Neosporosis and Trichomoniasis. Table 3 summarizes the common Mycotic and protozoan causes of bovine abortion.

Table 3. Common Fungal and Protozoan causes of Bovine abortion.

\begin{tabular}{|c|c|c|c|c|}
\hline S.No & Infectious agent & Time of abortion & Lesions & Samples for diagnosis \\
\hline 1. & $\begin{array}{l}\text { Aspergillussp (60- } \\
80 \% \text { Mucorsp,Absidia, } \\
\text { orRhizopus sp }\end{array}$ & $\begin{array}{l}4 \text { months to term } \\
\text { most common in } \\
\text { winter }\end{array}$ & $\begin{array}{l}\text { Placenta: severe, necrotising placentitis Cotyledons } \\
\text { enlarged, necrotic, intercotyledonary area is thickened } \\
\text { and leathery.Foetus: autolysed } 30 \% \text { have gray ringworm- } \\
\text { like skin lesions principally involving the head and } \\
\text { shoulders }\end{array}$ & Foetus, placenta \\
\hline 2. & $\begin{array}{l}\text { Tritrichomonas } \\
\text { (Trichomonas) foetus } \\
\text { Trichomoniasis }\end{array}$ & First half of gestation & $\begin{array}{l}\text { Placenta: retained, mild placentitis with hemorrhagic } \\
\text { cotyledons and thickened intercotyledonary areas covered } \\
\text { with flocculent exudates. Foetus: no specific lesions }\end{array}$ & $\begin{array}{l}\text { Placenta, foetus, } \\
\text { vaginal/uterine discharge }\end{array}$ \\
\hline 3. & $\begin{array}{l}\text { Neospora caninum } \\
\text { Neosporosis }\end{array}$ & $\begin{array}{l}\text { Any stage, but most } \\
\text { often } 5-6 \text { months }\end{array}$ & $\begin{array}{l}\text { Placenta, foetus: no specific gross lesions, autolysed. } \\
\text { Microscopic: focal encephalitis with necrosis and } \\
\text { nonsuppurative inflammation, hepatitis in }\end{array}$ & $\begin{array}{l}\text { Placenta, foetus (brain, heart, } \\
\text { liver, body fluids), serum from } \\
\text { the dam }\end{array}$ \\
\hline
\end{tabular}

\subsection{Mycotic Abortions}

Fungal or mycotic infection of the placenta is one of the most commoncauses ofsporadic bovine abortion[8]. Anywhere from $20-35 \%$ of abortions have been attributed to fungal causes. Abortion occurs when fungal spores enter a pregnant cow's blood stream (possibly through breaks in the lining of the upper digestive tract), settle at the junction of the maternal and foetal placentas, grow and attack the placental tissues. In general, fungal spores may be present in cattle feed. However, some feeds such as improperly preserved silage and hay that has been wet, contain many more spores than others[3].Aspergillus fumigatus accounts for 60 to 80 percent of abortions that are caused by fungal organisms. The organism may cause abortion from 4 months to term. Other species of molds and yeasts have been associated with abortion. Any condition that reduces the cow's resistance to infection increases the chances of mycotic abortion. Providing good health (via good management and nutrition) and not feeding moldy feeds can reduce the incidence. When possible, depending on the availability and demand decrease the period of confinement, decrease cow density, and improve ventilation[14].

\subsection{Trichomoniasis}

Trichomoniasis, is a venerealdisease of cattle. It is caused by theprotozoan, Trichomonas foetus. Theseorganisms are harbored in thereproductive systems of infectedanimals, and are transmitted from onecow to other cow by infected bulls. Cows will generally get rid themselvesof the disease after 60 to 90 days of sexual rest, but infected bulls appeartobe unable to develop immunity. Infertility is the most common clinical 
sign of a trichomoniasis infection[15].Abortion generally occurs early ingestation (first 3 months). Becauselittle tissue is shed during these earlyabortions, they often go undetected.Commercial vaccines are nowavailable. Proper immunizationrequires two injections, usuallyadministered two to four weeksinterval. Annual revaccination may berecommended.

\subsection{Neosporosis}

Neospora caninum is protozoa that can cause abortion early in the second trimester and infected cows can abort repeatedly. The definitive host for the organism is the dog that ingests tissue cysts. The cow then ingests sporulated oocysts in feed, water or soil contaminated with the dog feces. Tachyzoites can then be transmitted through the placenta to infect the fetus. Infected cows are asymptomatic[15].

\section{Prevention and Controlof Infectious Abortion in Bovines}

Due to the multifactorial aetiology of abortions in cattle, general prevention of non-infectious abortion concentrates on good husbandry, feeding and management. The control of infectious abortion is based on good disease control through closed herd policy, careful screening and quarantine of bought-in or introduced (e.g. rented bulls) animals and goodbiosecurity. Specific control measures for individual infectious abortive agents are presented under each disease. Once a sporadic abortion or an outbreak of abortions has happened, it is, in most cases, difficult to prevent further abortions from occurring unless the causative agent is identified and can be eradicated. In some cases, like IBR, further abortions will occur months after the first event.

The rapid detection and response to an emerging or reemerging disease is crucial. From the time this new disease develops until it is detected, a critical time period elapses. The rapid detection of such a new epidemiological event is therefore a key element for all policies to be developed. It is often the case that the disease will have spread undetected for a significant period of time before it is detected and reported. With globalization and the increase in speed and volume of international transport as well as passengers travel, emerging pathogens also begin their global voyage and spread. Rapid detection of emerging diseases is slow in many developing countries and some developed countries where there are possible deficiencies in the veterinary infrastructure, expertise, diagnostic laboratories and in surveillance capabilities as a whole especially for new diseases.

An important cornerstone of abortion control in a cattle herd is good record-keeping of abortion events, and identification, if possible, of the causes in each detected case of abortion. It is, therefore, good practice to investigate all abortions, even though only about one third of all laboratory investigations of abortions produce a conclusive result. Over a period of time, a picture of the herd's health status will emerge, and can be used to refine the Herd Health Plan to control disease. A systemic examination of all abortion cases should be carried out by a veterinary surgeon that will collect information on the history of the individual cow and the herd, examine the cow and the foetus (including placenta), collect laboratory samples and interpret results in connection with the cow and herd history. In some cases, samples will need to be taken as part of statutory disease control measures; therefore, allabortions should be reported to the farm's veterinary surgeon.

\section{Conclusion}

Even today bovine abortion is still remains a major economic problem in India.Numerous bacterial, viral, protozoan and fungal pathogens have been associated with abortion in cattle. These pathogens can result in substantial economic losses, indicating the need for control measures to prevent infection or disease. Prevention must be centered on keeping accurate records and collecting good samples for laboratory analysis and employing good biosecurity practices that inhibit the introduction and spread of infectious agents and utilizing vaccination programs could limit abortion occurrence. Maintain the general health and immune function of animals by providing a well-formulated ration, clean water and a clean/dry environment.

\section{References}

[1] A. De Vries. Economic value of pregnancy in diry cattle.Journal of Dairy Science. 89:3876-3885.2006.

[2] M.L. Anderson. Infectious causes of bovine abortion during mid- to late-gestation.Theriogenology. 68: 474-486.2007.

[3] B.C.Barr and M.L. Anderson. Infectious diseases causing bovine abortion and foetal loss. Vet. Clin. North Am. Food Anim. Pract.9:343-368.1993.

[4] N. Yang, X. Cui, W.Yu.S. Qian and Q.S.Liu. Survey of nine abortifacient infectious agents in aborted bovine fetuses from dairy farms in Beijing, China, by PCR. Acta Vet Hung. 60 (1):83-92.2012.

[5] M.J.Yaeger and L.D. Holler. Bacterial causes of bovine infertility and abortion. In: Youngquist RS, Threlfall WR, editors. Current therapy in large animal Theriogenology. 2nd ed., St. Louis: Elsevier. pp. 389-399. 2007

[6] M. Radostits, C. Gay, W. Hinchcliff and D. Constable. Veterinary Medicine, A text book of the diseases of cattle, horses, sheep, pigs and goats. 10th ed. Grafos, S.A. Arte Sobre Papel, Spain.280-352; 893-968.2007.

[7] D. Peter. Bovine venereal diseases. In: R.S. Youngquist, W.R. Threlfall, editor. Current therapy in large animal theriogenology. Philadelphia:W.B. Saunders Co. 355363.1997.

[8] R.LWalker. Mycotic bovine abortion. In: R.S. Youngquist, W.R. Threlfall, editors. Current therapy in large animal theriogenology.2nd ed., St. Louis: Elsevier.417-419. 2007.

[9] J.M. Miller and M.J. Van Der Maaten MJ. Experimentally induced infectious bovine rhinotracheitis virus infection during early pregnancy: effect on the bovine corpus luteum and conceptus. Am J Vet Res. 47:223-228. 1986. 
[10] B. Muylkens, J. Thiry, P. Kirten, F. Schynts and E. Thiry. Bovineherpesvirus 1 infection and infectious bovine rhinotracheitis. Vet Res. 38:181-209. 2007.

[11] F. A. Murphy, E.P.J.Gibbs, M.C. Horzinek and M.J. StuddertVeterinary virology. 3rd ed., San Diego: Academic Press.469-83.1999.

[12] D.L. Grooms. Reproductive consequences of infection with bovine viral diarrhea virus. Vet Clin Food Anim.20:5-19.2004.

[13] C.L. Kelling. Viral diseases of the fetus. In: R.S. Youngquist, W. R. Threlfall, editors. Current therapy in large animal theriogenology. 2nd ed., St. Louis, Elsevier. 399-408.2007.
[14] W.U. Knudtson and C.AKirkbride. Fungi associated with bovine abortion in the northern plains states (USA). $J$ Vet Diagn Invest. 4:181-185.1992.

[15] B. Abbitt, D.O. Rae. Protozoal abortion in cattle. In: R.S. Youngquist, W.R. Threlfall, editors. Current therapy in large animal theriogenology. 2nd ed., St. Louis: Elsevier.40913.2007. 